\title{
Civic Identities, Online Technologies: From Designing Civics Curriculum to Supporting Civic Experiences
}

\author{
Marina Umaschi Bers \\ Tufts University, Department of Child Development
}

\section{Scenario}

Peter is a twelve-year-old boy. He connects to Zora, a virtual city built and inhabited by eleven- to fifteen-yearolds. His avatar has his own face. Peter is happy because he feels that the virtual home he created in Zora is almost finished. He put pictures of his favorite things and people, and wrote stories about his family and friends. Peter decides to go around the virtual city. He quickly navigates through Zora's different public spaces: the Baptist Church, the French Chateaux, the Sports Arena and the Jewish temple. Upon entering the Jewish temple a virtual rabbi welcomes him with a blessing. "This is clever!" thinks Peter, "I will program my soccer player to welcome visitors to the Sports arena." The temple is populated by Jewish symbols and characters created by other Jewish kids. At first sight, there is a map of Israel, Hebrew letters, and a picture of a man praying. Peter navigates around the three-dimensional space and encounters many different objects. Peter decides to add a television to the temple. Inside it, he puts a snapshot from the movie Schindler's List that he found in the Web. He associates the value "documentation" to the television and defines it in the Zora Collaborative Values Dictionary as "it is very important to remember history. That way, bad things won't happen again. Holocaust survivors are getting very old now, and if someone doesn't record their stories of what happened, we are doomed to forget and repeat the horrors."

As he is about to leave the temple, he finds a case placed by Elena earlier that week. It has a Web link to a news article about a shooting in a Jewish community center. Peter clicks on the case and learns more about what happened. He also sees that Elena has used the Zora values dictionary to create a new value, "tolerance," and link it to the case. As Peter is reading Elena's definition of tolerance, the Zora mayor invites him to join a meeting in the virtual city hall.

This scenario describes an actual engagement by young people participating in a virtual summer camp with a three-dimensional multiuser environment called Zora. ${ }^{1}$ Zora provides easy-to-use tools for children to design and program their own virtual city and, in the process, learn new concepts and ways of thinking about identity and civic life. Children are put in the role of producers, instead of consumers, of information, knowledge, and habits of mind. The notion of youth as active cultural producers is a theme shared by most chapters in this

I am grateful to the following organizations that funded different aspects of the work presented in this chapter: Tisch College of Citizenship and Public Service at Tufts University, Academic Technologies at Tufts University, and NSF (NSF Career award "Communities of Learning and Care: Multi-user Virtual Environments That Promote Positive Youth Development," NSF IIS-0447166). The author is also thankful to members of the DevTech research group at Tufts University, in particular Clement Chau, Ashima Mathur, Daniela Mesalles, and Keiko Satoh, for their work on ACT. Finally, I'd like to thank Lance Bennett, the editor of this volume, for his constructive suggestions for improving this chapter, and the other contributors to this book for the wonderful exchanges and conversations we've had. 
volume. In Zora, this takes a different meaning because the environment provides a safe "social laboratory" ${ }^{2}$ for youth to experiment with some of the skills and attitudes needed to become good citizens. Zora is an example of a type of computational tool called identity construction environments (ICEs). ${ }^{3}$ ICEs are developed in the spirit of the constructionist philosophy of learning, which asserts that children learn better by doing creative things with computers. Thus software and hardware should provide authoring tools to enable children to make, design, and create digital artifacts while participating in a community of peers. Zora provides tools for youth to explore self and community by encountering the challenges of democratic participation. ${ }^{4}$

As shown in the short excerpt above, Zora engages children in thinking about issues of identity by inviting them to construct their own virtual homes and populate them with their most cherished objects, characters, pictures, stories, and personal and moral values. The city metaphor invites children to explore their civic identities by building the city's public spaces and by participating in a forum for discussing civic issues, as it will be later shown. Zora allows youth to participate in the virtual community not only by engaging in discussions and arguments, but also by designing and making new objects and new places within the virtual city, as a response to the virtual world's civic needs. ICEs, such as Zora, engage youth in chatting as well as doing, discussing as well as creating, and thinking as well as producing.

This chapter first provides a rationale for the need of developing educational programs for promoting youth civic engagement that make use of new technologies. Then, it presents a typology to guide the design of Internet-based interventions, taking into account both the affordances of the technology and the educational approach to the use of the technology. To illustrate this typology, examples of technology-based civic educational programs are presented. Later, it briefly presents the design of the Zora virtual environment, highlighting the features that support civic learning, and two different case studies in which Zora was used. It concludes with future directions for how to develop and use on-line virtual environments to promote civic engagement experiences that might transfer to the off-line world; and with reflections on how to make the contributions of this chapter "timeless," as lessons can be useful regardless of the technology in vogue in a particular time and location.

The typology of different interventions and the case studies illustrate what is possible in terms of civic education when providing young people with technological and media literacy skills as well as civic habits of mind in the context of an immersive virtual intervention. The notion of media literacy is further explored in Rheingold's and Levine's chapters. RaynesGoldie and Walker's chapter provide another example based on their extensive work done with the Web site TakingITGlobal.

\section{Virtual Environments: New Opportunities for Civic Engagement}

Today's youth are often criticized for their lack of civic participation and involvement in political life. Technology has been blamed, among many other causes, for fostering social isolation and youth's retreat into a private world disconnected from their "real life" communities. ${ }^{5}$ However, current research is beginning to indicate that today's youth are indeed engaged in civic life, but in ways very different from previous generations. First, youth tend to choose activism, volunteerism, and community work, as opposed to wellestablished means such as voting in elections or participating in political parties, as has been 
stated in different ways by Coleman, Earl and Schussman, Montgomery, and Raynes-Goldie and Walker in this volume. Second, technology—specifically the Internet-has provided a new way for youth to create communities that extend beyond geographic boundaries. These virtual communities enable youth to engage in civic and volunteering activities across local communities and national frontiers, to learn about political life, and to experience the challenges of democratic participation. ${ }^{6}$

However, although there is a growing body of research indicating the educational and social potential of the Internet, ${ }^{7}$ there have been few studies conducted to purposefully evaluate technology-based interventions in the area of civic engagement. Since virtual environments can provide quick access to a wide range of information and resources, communication mechanisms for engaging in critical debates, ${ }^{8}$ and tools for supporting collaboration and for enabling new expressions of social life, ${ }^{9}$ they can serve as powerful platforms for developing educational programs to promote civic education. In a test-driven educational atmosphere in which most public schools might not be able to devote resources and time to increase student's civic participation, the potential of new technologies is even greater for reaching those same students when they are outside of school and connecting to the Internet from their homes. Virtual communities, simulations, or interactive games specifically designed with civic education goals might offer a space for young people to become civically engaged-at least in the on-line world.

Although preliminary studies have shown the potential of new technologies to engage young people in on-line civic life, there is a need of more research looking at how technologybased interventions particularly aimed at fostering civic engagement can promote participation not only in the virtual world, but also in the face-to-face world.

While participation in virtual life does not replace traditional civic actions, research shows that adults are more likely to vote and be engaged in the civic sphere if, as youth, they were involved in community-based organizations or extracurricular activities. ${ }^{10}$ As the Internet is becoming a new way for youth to form community-based organizations and to spend a big portion of their after-school time, it is plausible that future research will show that youth who are more active on-line will also grow into more engaged citizens.

For example, pilot work by Chau suggests that college students who possess high level of interpersonal technological abilities (i.e., who use technology to establish connections with others) may use the Internet in manners that are more conducive to building connecting and caring relationships with peers than would students with lower level of interpersonal technological abilities. Thus, youth who are low on internal technological efficacy may benefit most if provided first with educational opportunities to develop technological competence and a sense of confidence in their technological skills. ${ }^{11}$ This early work indicates that it is important to understand and evaluate youth's technological competencies, before developing specific technology-rich educational interventions.

While technological competence is a prerequisite for youth to fully benefit from these programs, if the end-goal is to promote civic engagement, it is imperative to understand our philosophical and pedagogical stance regarding civic education. Do we want to use technology to design interventions that will help youth to develop civic skills, such as deliberation and decision making? Do we want to expose youth to opportunities that allow them to actively participate in community life through the use of technology? Or is our goal to provide technological environments in which youth can develop civic identities grounded on personal and moral values such as social justice? These different options are not mutually exclusive, and the best interventions integrate all of them. 


\section{From Civic Skills to Civic Identities}

Once in the Zora City Hall, Peter joins a conversation about the case placed by Elena with a Web link to a news article about a shooting in a Jewish community center.

Elena says: It was very scary. I read the article and one of the things the man who committed this act said is that he wanted to remind people that all Jews should be killed. That sent serious shivers down my spine.

Kosho says: Nazis. A leader tells them that others are the cause of all their problems.

Peter says: Some people are just looking for someone to blame.

Janet says: People are gonna feel the way they want to feel and no one can really change their minds

Elena says: They are entitled to their opinions but it's their actions that need to be stopped. Janet, do you really think that? No one can change their minds? And if it's true that we can't change their minds, should we do something to limit their actions?

Peter says: There isn't anything we can do.

Nino says: This guy should be dragged out and flayed alive.

Kosho says: You just can't fix a wrong with a wrong.

Janet says: Yeah, violence is never the answer.

Nino says: If anybody deserves the death penalty, he does.

Peter says: But I think no one deserves the death penalty.

Carla says: He should just have life in jail.

Sheila says: He shouldn't be shot but helped, I really don't know how, but he just needs a way to get familiar with other cultures.

Nino says: That's not going to help. Death penalty.

Peter says: We don't have the authority to take a person's life. Death penalty is still not justified.

Sheila says: I think by killing him we show that we have given up and the only way to solve things is to kill somebody, and I know that is not right.

Matrix says: I read an editorial that said people should just be put in jail for life because, believe it or not, the death penalty cost more than letting him live for the rest of his life (30 yrs.).

Elena says: Answer my questions, should anyone who kills be killed? Or does intent matter? And if intent matters, does it matter more or less than the result of the action?

Nino says: Intent and result both matter.

Elena says: And once he is killed, assuming he is, what would be the repercussions of that? Would his family go after the government? Would he become a neo-Nazi martyr?

Janet says: Maybe there should be a boot camp for people like this.

Peter says: It wouldn't really work. The only prevention is at home. People need to be brought up knowing discrimination is wrong. 
Sheila says: I think we can't do that much for adults, but the kids in school I know we can do a lot, so I think we should try to concentrate on making sure they know that this stuff is wrong.

While this on-line conversation continues, Ernie, one of the youngest and shyest children using Zora, who is very quiet "listening" but is too shy to participate, starts to make a new virtual place, the "Everyone's Temple," which he describes as a space for "all the cultures and religions to get along."

This example of the type of exchanges that happen in Zora points us in two different directions that this chapter follows. ${ }^{12}$ First, the design considerations, both from a pedagogical and a technical perspective, that need to be taken into account when designing virtual environments that, beyond providing civic knowledge and information, afford opportunities for learners to engage in civic discourse and civic action. Second, the civic education approach used when developing these technologically rich interventions. On one side of the spectrum, civic education can take a behaviorist approach (i.e., providing skills and knowledge that might be useful for both living in a civil way and contributing to civil society). On the other side, it can take a psychological approach (i.e., focusing on helping children to develop civic identities by exploring personal and moral values deeply rooted in their own sociocultural and religious backgrounds). It is important to understand where in the spectrum we situate our educational programs so as to choose the best possible use of technology and the design features of the software.

The first question regarding pedagogical and technical considerations is addressed in the section "Educational Technologies and Civic Education," which looks at the different ways in which technology can be used to teach and to promote learning. A typology and examples are presented. The second question regarding approaches to technology-based civic education programs is addressed by presenting case studies of how a particular kind of technology, the Zora identity construction environment, was developed to integrate and combine both behaviorist and psychological approaches.

The goal of helping children to clarify their values as a first step toward civic engagement is not new in education, neither is it associated with the use of technology. However, new technologies such as multiuser virtual environments have the potential to amplify the experience by situating personal values in the context of a living community. When Lawrence Kohlberg, the well-known academic of moral reasoning, proposed the "just community" model as a safe educational space critical in shaping an individual's moral development, ${ }^{13}$ he realized the importance of a community for advancing moral thinking and moral behaviors. Thus, as opposed to his most well-known work on moral reasoning (which focused, in the Piagetian tradition, on asking children to solve isolated moral dilemmas and assigning them to a particular moral reasoning stage), Kohlberg realized that a moral community was needed to breed moral individuals. In Kohlberg's "just community" program, students and teachers engaged in conversations about dilemmas and controversial issues similar to the ones described in Zora. However, members of these just communities could make decisions about all aspects of the community life, except curriculum decisions. This is a very important difference with the type of educational work that happens in virtual communities such as Zora.

There are three major differences between the just community educational approach and the experiences afforded by participating in Zora. Some of these differences are due to the choice of media (virtual environments vs. face to face) and others to the pedagogical stance. First, as shown by the examples presented earlier, community members do not follow an already-established curriculum specifying the activities they should engage in. They are 
empowered to decide what kind of projects and discussions they would work on. Thus, they engage in what Hart describes as one of the highest levels in the ladder of civic participation observed in children, child initiated and directed projects. ${ }^{14}$ Second, Zora makes it easy for learners to observe the connections between what is said in the on-line conversations (i.e., discussion about discrimination) and what is done in the virtual city (i.e., creating the "Everyone's Temple"). An environment that offers the possibility of observing the relationship between saying and doing is powerful because in issues of identity and values, community and civics, concrete actions matter as much as analytical thinking. ${ }^{15}$ In the real world, however, taking action would involve a long-term complex process for young children. Third, in Kohlberg's work, the tools people have to build a just community are words and their derivates such as meetings, sharing stories, discussing dilemmas, etc. In Zora, as shown by Eric's "Everyone's Temple," people can also engage in making concrete artifacts, such as virtual places, that can be used and inhabited.

Regardless of these major differences, Zora and the just community model share a similar educational purpose: the development of an educational approach to engage children in developing a community with the goal of learning about moral values, explore the civic aspects of the self and exercise civic skills by making decisions about community life. In the process, civic identities are developed and public voices, as discussed in Rheingold's chapter, start to emerge.

\section{Educational Technologies and Civic Education}

Kohlberg's just community is one of many civic education programs. I use it in this chapter as an example of what has been called praxis-based educational models. These are developed to give people the experiences through which they can become effective citizens. ${ }^{16}$ Praxisbased models are in sharp contrast with knowledge-based models focused on what people should know and understand about citizenship.

These distinct approaches propose different pedagogies concerned with how best to support learning, and different epistemologies, concerned with the question of what is considered learning. While knowledge-based models pay attention to the teaching curriculum, praxis-based models are concerned with how young people can be given opportunities for engagement and decision making in their communities. The challenge is how to reconcile these models in the test-driven and politically confined environment of most public schools.

The distinction between knowledge and praxis permeates the world of education and is consistent with two different approaches for developing educational technologies, identified by Seymour Papert, pioneer in the field, as instructionist and constructionist. While the instructionist approach sees the effectiveness of a technology as situated in its instructional efficacy, and therefore its potential for transmitting knowledge and information, the constructionist approach conceives the computer as a tool to help learners have experiences that will support their own construction of knowledge.

Within the instructionist way of using technology for education, which is closely aligned with the knowledge-based model proposed in civic education mentioned earlier, two major paradigms have emerged: computer-assisted instruction (CAI) and intelligent tutoring systems (ITS). ${ }^{17}$ While most of the educational technologies designed with the CAI paradigm serve as a new medium for the presentation and delivery of information to students in the form of drill and practice, the ITS paradigm aims at creating educational software that adapts itself to the user. Unlike static CAI applications, ITS educational software incorporates an 
interactive component, with each student receiving a different type of instruction based on skill level and ability.

While instructionism-and its two paradigms, CAI and ITS-focuses on the role of technology to do better teaching by providing better ways of transmitting information, constructionism asserts that computers are powerful educational technologies when used as tools for supporting the design, the construction, and the programming of personally and epistemologically meaningful projects that engage learners in new experiences. Constructionism is rooted in Piaget's constructivism, in which learning is best characterized as an individual cognitive process given a social and cultural context. However, whereas Piaget's theory was developed to explain how knowledge is constructed in our heads, constructionism, developed by Papert, pays particular attention to the role of constructions in the world as a support for those in the head. Thus, constructionism is both a theory of learning and a strategy for education. It offers the framework for developing a technology-rich design-based learning environment, in which learning happens best when learners are engaged in learning by making, creating, programming, and communicating.

Constructionism also has two major paradigms: the Logo-inspired programming languages for children, and the computer-supported collaborative learning movement. Constructionism views the programming of a computer as a powerful way to gain new insights into how the mind works and learns. Thus, it advocates for providing children with an opportunity to become computer programmers as a way to learn about different content areas (in particular mathematics and science) but, more important, to learn about learning. Papert argued that using a child-friendly version of the programming language LISP, called Logo or the language of the turtle, was an easy and natural way to engage students in programming. Logo allows students to actively create artifacts in a process of discovery-based learning-a process directly aligned with the praxis-based model of experiential learning. By now there is a long-standing constructionist tradition of authoring tools and programming environments that follow the Logo steps. Some of these technological environments are designed for children's learning about mathematics and science, ${ }^{18}$ for creating virtual communities to foster peer learning and collaboration and for designing computational environments to promote positive youth development through storytelling. ${ }^{19}$

The other paradigm within constructionism is computer-supported collaborative learning. This most recently developed paradigm shifts the process of cognition as residing within the head of one individual to the view that cognition is situated within a particular community of learning or practice. ${ }^{20}$ Therefore, educational technologies designed within this paradigm take seriously the need to provide tools for community building and community scaffolding of learning. Thus the focus is on creating social environments in which constructionist types of learning activities using technologies can happen. This pedagogical switch from learning as an individual experience, which was rooted in Piaget's theories, to learning as a social process, which is rooted in Vygostsky's theory, occurred concurrently with the fast-growing uses of the Internet in education and the development of virtual learning communities.

Aligning instructionist technologies with knowledge-based approaches to civic education, and constructionism to praxis-based approaches, provides a framework for thinking about the different ways in which new technologies, in particular the Internet, can be used for developing civic education programs and for distinguishing the pedagogical and technological affordances of the different approaches (see Figure 1). Both approaches can take a behaviorist or a psychological stance, or a combination of both, depending on the choice of primary learning outcomes, civic skills or civic identities. 


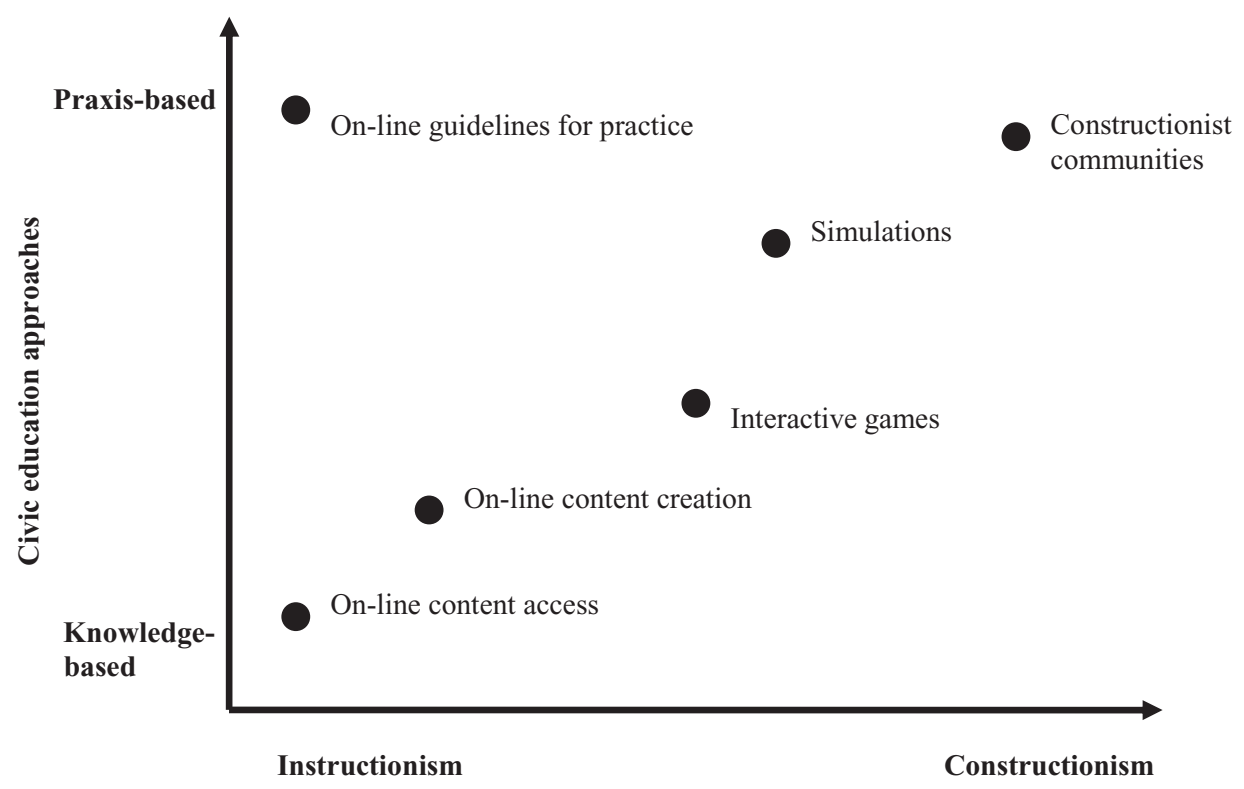

Educational technologies approaches

Figure 1

A typology for integrating approaches to civic education and educational technologies.

Figure 1 shows a typology emerging from intersecting civic education approaches with educational technologies approaches. By analyzing technology-based civic education programs, six distinct categories emerged in the typology. The first three categories refer to programs that provide opportunities for youth to access and create on-line content, as well as encounter on-line guidelines for practice. The other three refer to programs that provide learners with opportunities to immerse themselves in the civic realm by playing interactive games, participating in simulations, or developing constructionist communities.

Table 1 provides examples of technology-rich civic education programs within each typology. For a different kind of typology that looks at the content of the Web sites, regardless of the affordances of the technology regarding a particular stance toward civic education, refer to the March 2004 report "Youth as E-Citizens: Engaging the Digital Generation" by Montgomery et al. ${ }^{21}$

In the next sections I will present work done with Zora, an example of a constructionist virtual community, as a way to elucidate what represents for me the full potential of using technology to develop praxis-based programs that integrate behaviorist and psychological approaches to civic education.

However, although praxis-based programs are at the heart of what I consider powerful educational experiences using technology, this view is not always in agreement with current trends in the American educational system that tend to focus on knowledge-based programs in which students can be assessed using traditional means such as comprehensive multichoice exams.

The typology and the continuum of instructionist to constructionist approaches need to be problematized. For example, one of the reasons that programs such as Student Voices fall 
Table 1

Examples of different online approaches to civic engagement and education

\begin{tabular}{|c|c|c|c|}
\hline & Program & Web site & Description \\
\hline $\begin{array}{l}\text { On-line guide- } \\
\text { lines for practice }\end{array}$ & Youth Voice. Net & $\begin{array}{l}\text { http://www.indiana.edu/ } \\
\text { \%7Eythvoice/socialtools. } \\
\text { html }\end{array}$ & $\begin{array}{l}\text { This Web site provides } \\
\text { guidelines on how to } \\
\text { be an advocate at the } \\
\text { community level or in } \\
\text { local or state politics. It } \\
\text { provides resources for } \\
\text { promoting civic } \\
\text { engagement. }\end{array}$ \\
\hline \multirow[t]{2}{*}{$\begin{array}{l}\text { On-line content } \\
\text { access }\end{array}$} & Student Voices & $\begin{array}{l}\text { http://student- } \\
\text { voices.org/ }\end{array}$ & $\begin{array}{l}\text { This Web site is aimed at } \\
\text { engaging youth in } \\
\text { politics. It provides } \\
\text { discussion forums and } \\
\text { educational links. It is } \\
\text { well organized and } \\
\text { clearly youth oriented. } \\
\text { It includes ways to get } \\
\text { involved in society } \\
\text { both on the local and } \\
\text { national level. }\end{array}$ \\
\hline & $\begin{array}{l}\text { Campus } \\
\text { Activism.Org }\end{array}$ & $\begin{array}{l}\text { http://www. } \\
\text { campusactivism.org/ }\end{array}$ & $\begin{array}{l}\text { Interactive Web site } \\
\text { aimed at college } \\
\text { leaders. It offers } \\
\text { networking with other } \\
\text { college groups. Web } \\
\text { site includes forums, } \\
\text { online resources, } \\
\text { calendars of events, } \\
\text { e-mail lists, and lists of } \\
\text { current and past } \\
\text { campaigns. }\end{array}$ \\
\hline \multirow[t]{2}{*}{$\begin{array}{l}\text { On-line content } \\
\text { creation }\end{array}$} & $\begin{array}{l}\text { CholertonShand } \\
\text { Online Consultation } \\
\text { Platform }\end{array}$ & $\begin{array}{l}\text { http://www. } \\
\text { cholertonshand.co.uk/ } \\
\text { document. } \\
\text { asp?id=15 }\end{array}$ & $\begin{array}{l}\text { This program, which } \\
\text { mostly uses chat, } \\
\text { e-mail, and interactive } \\
\text { questionnaires, surveys } \\
\text { and consults young } \\
\text { people in political } \\
\text { matters. It collects } \\
\text { information about } \\
\text { citizenship provided by } \\
\text { youth. }\end{array}$ \\
\hline & Taking ITGlobal & $\begin{array}{l}\text { http://www. } \\
\text { takingitglobal.org/ }\end{array}$ & $\begin{array}{l}\text { This highly interactive } \\
\text { Web site presents an } \\
\text { on-line international } \\
\text { community aimed at } \\
\text { getting youth involved } \\
\text { at the local and global } \\
\text { level. The Web site } \\
\text { offers blogs, discussion } \\
\text { boards, member } \\
\text { profiles, and }{ }^{22} \text { links. }\end{array}$ \\
\hline
\end{tabular}


Table 1

Examples of different online approaches to civic engagement and education (Continued)

\begin{tabular}{|c|c|c|c|}
\hline & Program & Web site & Description \\
\hline $\begin{array}{l}\text { Interactive } \\
\text { games }\end{array}$ & DemGames & $\begin{array}{l}\text { http://www.delib.co.uk/ } \\
\text { knowledge_centre/ } \\
\text { case_studies/ } \\
\text { demgames }\end{array}$ & $\begin{array}{l}\text { This series of games was } \\
\text { developed with the purpose } \\
\text { of teaching about democracy } \\
\text { and citizenship through an } \\
\text { interactive manner. The } \\
\text { games are available online or } \\
\text { through a CD. They include a } \\
\text { teacher support pack. } \\
\text { Demgames is being used in } \\
\text { youth councils (twelve to } \\
\text { eighteen year olds) to engage } \\
\text { new participants and educate } \\
\text { members. The technology is } \\
\text { Blue-Tooth compatible and is } \\
\text { being tested on mobiles. }\end{array}$ \\
\hline Simulations & Smart/Sheffield & $\begin{array}{l}\text { http://www.delib.co.uk/ } \\
\text { knowledge_centre/ } \\
\text { case_studies/ } \\
\text { smart_connect }\end{array}$ & $\begin{array}{l}\text { This textual-based interactive } \\
\text { program promotes civic } \\
\text { engagement by engaging } \\
\text { youth in the discussion of } \\
\text { citizenship-related issues. }\end{array}$ \\
\hline \multirow[t]{2}{*}{$\begin{array}{l}\text { Constructionist } \\
\text { communities }\end{array}$} & Zora & $\begin{array}{l}\text { http://www.ase.tufts. } \\
\text { edu/devtech/ } \\
\text { vclc/CHZora.html }\end{array}$ & $\begin{array}{l}\text { 3D multiuser environments } \\
\text { that provides tools for youth } \\
\text { to create and inhabit a virtual } \\
\text { city, by creating virtual } \\
\text { spaces, objects, characters, } \\
\text { stories, and a values } \\
\text { dictionary, as well as engage } \\
\text { in debate over cases and } \\
\text { real-time interactions. }\end{array}$ \\
\hline & Quest Atlantis & $\begin{array}{l}\text { http://atlantis.crlt. } \\
\text { indiana.edu/start/ } \\
\text { index.html }\end{array}$ & $\begin{array}{l}\text { 3D multiuser environment in } \\
\text { which users undergo tasks or } \\
\text { quests. Users are engaging in } \\
\text { an already created world. } \\
\text { Participants chat among } \\
\text { themselves and with mentors. } \\
\text { Quests have specific } \\
\text { educational purposes and are } \\
\text { associated with social or civic } \\
\text { responsibilities. }\end{array}$ \\
\hline
\end{tabular}

in the left lower corner is that these programs are aimed at being realistically integrated with test-driven curricula. Virtual environments such as Zora provide flexibility regarding this. For example, if used in the context of public schools, the Zora curriculum can be strengthen thus taking the experience into a more knowledge-based model.

\section{Zora: Developing Civic Identities}

Zora is an example of a constructionist virtual community specifically designed to promote positive youth development. Positive youth development involves cognitive, personal, 
social, emotional, and civic aspects of adolescence, which researchers refer to as the six C's: competence (cognitive abilities and behavioral skills for being healthy), connection (positive bonds with people and institutions), character (integrity and moral centeredness), confidence (positive self-regard, a sense of self-efficacy), caring (human values empathy and a sense of social justice), and contribution (orientation to contribute to civil society). ${ }^{23}$ Together, these characteristics reflect a growing consensus about what is involved in healthy and positive development among people in the first two decades of their lives.

Within this framework, the sixth $\mathrm{C}$, contribution to civic life, plays an important role because it is a predictor of the positive direction toward which an individual is moving in his or her developmental trajectory. Zora has design features that promote each of the C's by providing tools for users to create and inhabit a virtual city and, in the process, learn new things about identity and civic life.

Zora's design and infrastructure provides a bridge between what I have called earlier behaviorist approaches to civic education, focused on helping children become better citizens by teaching them civic attitudes and skills such as respectful argumentation, debate, information literacy, and so on, and psychological approaches focused on internal motivation to support the development of morally responsible individuals who will shape a morally responsible and civically minded society. These can help children to discover their personal and moral values as inspirations and compasses for developing a civic self concerned with issues of equality, morality, and social justice.

In Zora, behavioral and psychological approaches are integrated by providing computational tools for children to create a virtual city with private and public spaces. They can navigate the three-dimensional space with their avatar of choice and chat in real-time. For example, each user creates his or her personal home and populates it with objects and characters. For each of them, children create a story to describe it and assign a value and its corresponding definition to indicate why the creation is personally meaningful and what moral message the object/character carries. For example, as shown in the example presented earlier, Elena had created a TV with the movie Schindler's List and had assigned and defined the value "documentation." All of the individual values and definitions created by children are updated into the Zora's collaborative values dictionary, which serves at least two different functions. First, it provides a way to understand the "moral climate" of the virtual city. Second, it engages Zora users in different activities to decide which of those values they want to keep as flagship for their city, which ones need some discussion because there is disagreement about their meaning (i.e., different users have entered a same value but define it in different ways), and which others will serve as the basis for developing the city's constitution, mission statement, and code of conduct.

As mentioned above, Zora's design supports both behaviorist and psychological approaches to civic education. In terms of promoting behavior changes, the most salient design features are "cases." A case is an object with a particular kind of shape and graphical image representing an event or a circumstance to be discussed and agreed upon by all community members. In the same spirit as a legal case, a Zora case requires community members to engage in debate and take action to resolve conflicts. This kind of participation in a learning environment might serve as a model for the larger political community in which children will participate as adults. Users can create new cases as new issues arise.

For example, in the scenario presented before, Elena had put a case with a link to a news article about an anti-Semitic incident. The fact that it was a "case," and not only an object, indicated to the Zora citizens that Elena wanted to have a discussion about it and prompted 
the Zora city mayor to call for a meeting in the City Hall. Once there, the exchange evolved from discussing anti-Semitism, racism, and xenophobia to debating about the fairness and usefulness of the death penalty, as well as preventive mechanisms for educating young people against hate crimes. While this case was about a current event reported in the newspaper, and thus engaged children in thinking about the impact on society at large, other cases are only relevant to Zora, such as those dealing with setting up the social organization of the virtual city, such as "I think that people should not change or put things in other peoples [sic] rooms. Unless they have permission," or "Anyone should be able to drop anything anywhere, but with a consequence. This should be like breaking a law, punishable by imprisonment of one hour."

Zora's design features that support a behaviorist approach, such as cases, are grounded on understanding civic education as a deliberative and argumentative process that helps children take on civic behaviors. Thus, the children's experience in Zora should serve them as a playground for experimenting with the ways of thinking and behaving needed to function in a community, in particular with the complexities involved in self-organization, government, and decision making, This is consistent with extensive research that suggests that the involvement in participatory democracy, social institutions, group decision making, and self-government are critical in shaping individuals' moral development.

Moral development is an important aspect of what I have called the psychological approach to civic education. Some of Zora's design features are developed with this in mind. For example, the collaborative values dictionary, which was described earlier, helps children to develop a sense of identity by asking them to think about their most cherished personal and moral values and how they have influenced their creations in the world. There is another type of object, called heroes and villains, which have special attributes and serve as models of identification and counteridentification. As the American psychologist Erik Erikson points out, "no ego can develop outside of social processes that offer workable prototypes and roles." ${ }^{24}$ Thus, creating Zora's heroes and villains provides a way for children to engage in the dynamic process of identifying with and differentiating from others, which is essential to form a coherent sense of self. The values dictionary and the heroes and villains are the most notorious Zora's features explicitly designed to support building civic identities which are morally grounded and that invite children to explore, understand, and reflect about personal and moral values.

While some of these design elements are unique to Zora, they are also present in many of the technologies and tools mentioned in the typology of educational technologies for civic engagement presented earlier. For example, different forms of media production focused on civic engagement, such as the weblogs and the wikis presented by Levine's and Rheingold's articles and the on-line petitions described in Earl and Schussman's chapter can provide mechanisms for promoting collaboration, including comprehensive Web sites such as TakingITGlobal, described in Raynes-Goldie and Luke's article, which can offer opportunities for taking global civic action.

In the next section I describe an educational program, Active Citizenship through Technology (ACT), developed using the Zora environment, to help precollege students to develop civic identities, while forming a community of peers and social support network.

\section{Using Zora to Create the Virtual Campus of the Future}

Mike says: Anyone have strong feelings about the admission process? 
Laura says: I think that peer review will be a better way at processing people. Maybe on a sub-personal level.

Caitlin says: To what degree?

Tom says: What do you mean by peer review?

Make says: Would peer review take the place of an essay?

Laura says: Like interviews.

Kim says: More like having admitted students read applications and give their feedback; the common applications with a supplemental essay.

This is a log excerpt from a real-time conversation in Zora by a group of Tufts University incoming freshmen who participated in the optional preorientation program, ACT, developed by Bers. ${ }^{25}$

ACT is both an educational and a research program. Students come together for three days to use Zora to create and inhabit a virtual campus of the future. At the end of the intensive program, they make a short digital video, or infomercial, about their virtual campus. During their first semester in college, students came together again in an open house to show their infomercials to the campus community. During their four years in college, ACT participants are asked to complete surveys and participate in focus groups in an effort to collect data regarding the impact of ACT in their academic and extracurricular experiences.

The ACT curriculum is designed so students, in the process of developing their campus of the future, can first learn about the real campus by interviewing faculty, students, and administrators and then discuss how they could improve its facilities, its policies and curricular offerings and, most important, what is the relationship between their campus and their surrounding community and what are student's civic privileges and responsibilities toward the local neighborhoods and international communities.

In the spirit of a constructionist community, the goal of ACT is to immerse youth in a hightech playground where they can acquire civic knowledge and skills as well as experiment with civic behaviors and democratic participation. These will be useful not only for growing as committed citizens, but also for adjusting to their new community, the university campus.

During the first two years of running the ACT program, while most of the discussions in Zora were about building a stronger community within the campus, some started to explore how to build relationships between the campus and the surrounding neighborhoods. These discussions were supported by the creation of virtual exhibits displaying issues of concern in the Zora campus of the future.

The ACT intensive program, which takes place at the end of the summer just before participants' matriculation to the university, has several goals. First, to engage incoming freshmen in a fun activity that leverages on their interest on interactive games and virtual communities. Second, to help them to connect with each other and to find a social support network early on, before the stress of the academic year begins. Third, to promote civic engagement both at the campus and the community level. ${ }^{26}$

Some conceive civic engagement as being a good neighbor, obeying rules, and participating in the community; others think of it as engagement with political processes such as voting. In the work presented with Zora, the notion of civic engagement goes beyond a focus solely on the procedural aspects of democracy to one that embraces the many facets of a deliberative democracy in one's own environment, school, local community, or larger society. This includes the ability to engage in civic conversations, to develop civic knowledge, skills, 
attitudes and behaviors, and to participate in community service, activism, and advocacy. Since the ACT program is conducted with freshmen, civic engagement is primarily defined as all of the above in the context of college and campus community.

As mentioned before, ACT is part of an ongoing multiyear longitudinal pilot study in which two cohorts of students participate in the preorientation program using Zora and are followed through their academic career by collecting participant data via multiple means. First, the Zora environment readily provides a log of all online activities and conversations that happen throughout the program. Log files from the program are read and coded by orientation peer leaders and researchers. Second, exit focus group interviews and surveys to collect overall feedback about the program as well as suggestions for improvement of individual sessions and activities is requested from participants. Third, once a year, participants complete followup surveys, which are used to assess the carry-over effect of the program on participants' active involvement on campus and in the surrounding community. Data from a randomized control group (i.e., a randomized group of other students on campus of the same cohort who did not participate in ACT) are collected each year as comparisons. To date, two cohorts of students have participated in ACT. The first consisting of eighteen students, the second of twenty-one. Participants in the first cohort came back to the second group as peer leaders.

The first cohort of ACT participants chose to use Zora to develop a virtual campus very focused on student's own interests and needs. For example, they built the "Campus Safety Center," which offers "a shuttle service for 18 hours a day followed by a campus cab system that goes anywhere in a 5 mile radius of the campus, and the 'Jumbo Appetite,' a dining hall where themed meals are served and a suggestion box where requests for particular foods can be made."

During the three-day period each student created his or her own virtual dorm room. They downloaded favorite sports team images, pictures of famous singers, and other images

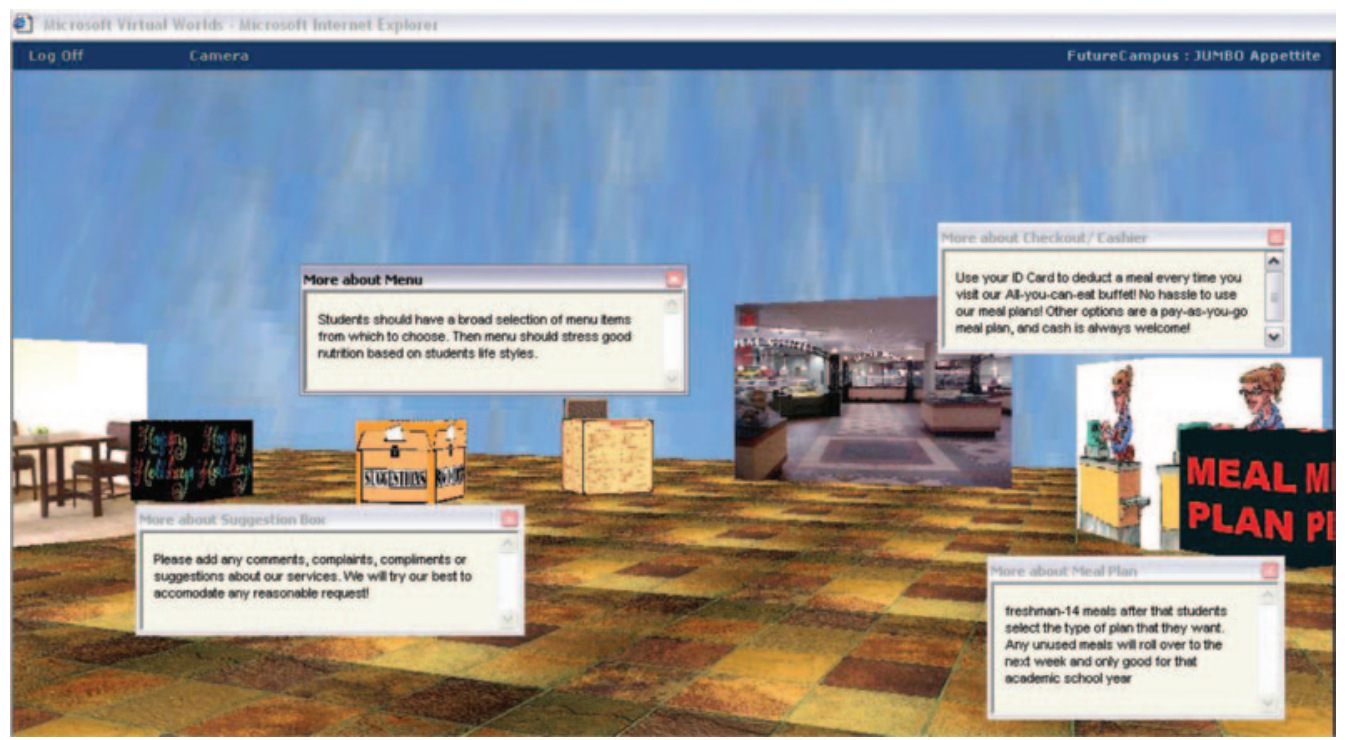

Figure 2

Jumbo Appetite, the restaurant in the virtual campus. 
to decorate their virtual walls. Overall, they created sixteen public spaces, such as the Mike Jonas Student Center, the Sports Center, the Math and Science Building, the Orwell Language Hall, the Winifred Mandela Library, and so on. After on-line brainstorming about some basic houses that were needed, students began working alone. For example, one student created a computer room for the campus as he is planning on being a computer science major. He described it as follows: "The computer spot is a computer lab where all activity is subject to surveillance in order to protect against illegal actions. There is also a university Cellphone Network. The university will provide each student with a free cell phone and will have its own network, where all students and faculty can call each other for free."

As individual locations started to appear, and not everyone agreed on the purpose and facilities offered, the group decided they needed to come together and finalize a plan to complete their campus instead of working separately without discussing what they are doing. They discussed several cases as a group and divided up tasks. Students assigned each other rooms to create, and deadlines for completion were agreed upon. The group decided that the content presented in each house was more important than its aesthetic appearance; therefore, they focused on developing well-written descriptions, stories, and values associated with objects. For example, they chose the following values in their collaborative values dictionary as the most important to guide behaviors in their virtual campus: Academic Curiosity, Cooperation, Tolerance, Perseverance, Respect, Integrity, Leadership, and Respect.

The beginning of self-organization and self-governance started to appear on the second day of the program. They discussed issues such as student life, policies/rules for graduation, Internet, administration, and student services. Following is an excerpt of a conversation in which students discussed funding for students' clubs.

Peter says: Are we going to have fun student clubs? Do clubs have to give back to the community?

Melanie says: If you are giving back to the community, should you get more money?

Alan says: Should we fund the clubs?

Peter says: Every year, they give their proposal... then they decide... and get their permission.

David says: If you are giving back to the community, you should get money. Why put money into clubs?

Peter says: If it lasts then that is good; but if you are new, you start-off with the minimum amount.

As shown in this excerpt, most of the on-line discussions focused on internal issues to campus life. Civic engagement was conceived as a process of becoming involved with the civic life of campus, such as assigning internal budgets or developing policies that would be best for students. While this was one of the goals of the ACT program, in this first experience, students did not explore the relationship between campus and community. Data from focus groups showed that since students were just entering into a new community (the college campus) they first needed to understand and master it, and then venture out of the hills of the university. As the ACT curriculum was focused on giving students the freedom to pursue their own interest in an effort to give them ownership over their virtual campus, the lack of connection between college civic life with the broader community is not surprising. 


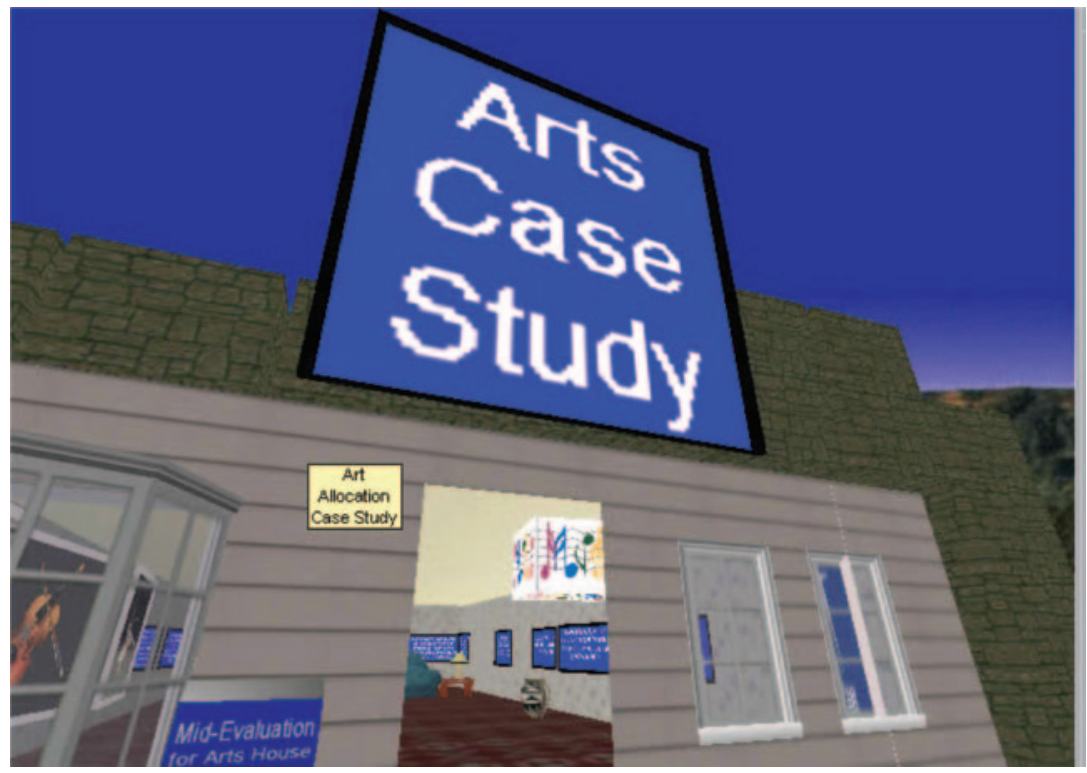

Figure 3

A virtual exhibit about the importance of art education programs in schools.

Based on this finding, the next year, the second cohort of ACT participants was exposed to a curriculum that focused on developing a civically engaged virtual campus with strong connections with the surrounding community. For example, students were asked to investigate the living conditions and the educational and health situation of the campus neighborhoods and propose recommendations of how their future virtual campus could have an impact on this.

For example, some students chose to focus on the relationship between the local town police and the university police. They conducted research to analyze if and how both groups interact and they interviewed police officials to understand better if and how the surrounding community benefits from the campus police. Other students chose to focus on the role of the universities, in particular the education, child development, and psychology departments, to provide child care and educational opportunities for members of the surrounding community.

Some students chose to do research about issues of public interest such as the impact of comprehensive exams in the learning environment and state-mandated curriculum, and the positive impact that athletics programs and art education programs can have on a local community (see Figure 3). Instead of writing their ideas and results of their research in a paper or action plan, they used Zora to develop a virtual exhibit to teach others about their findings. The interactive nature of Zora allowed participants to use the tool for both the process and the product, as well as to invite contributions from other ACT participants who did not choose to work on these issues.

In the ACT experience described above, two cohorts of incoming freshman used Zora to design and inhabit a virtual campus of the future. As one of the participants in the first group said, "I did not really learn much about civic engagement ... well ... actually if I wanted to become a senator ACT would have been very useful." 
This student realized that through his experience in ACT he started to gain the skills needed to participate in public life, such as making decisions that might have a broad impact and engaging in thoughtful debate and argumentation. But most important, he started to develop a civic identity that prompted him to look beyond his own interests and to take into consideration the public's best interest.

However, this student did not understand that, although the skills he learned in ACT are useful for becoming a senator and participating in the civic life of the country as a leader, they are also useful to becoming a positive contributor to civic society from many other roles. Even more important, while ACT might have been useful to this particular student, skills and identities do not develop in three days, but over time. Research has shown that engaging young children in civic activities from an early age is a positive predictor of their participation in later civic life. This explains the effort to work with young children, as I did in the context of a summer program for children aged eleven to sixteen who used Zora to develop their virtual city, from which excerpts of the scenario presented at the beginning of the paper were taken. ${ }^{27}$

\section{Future Directions: From Online to Offline Experiences}

Zora is one of the many tools available today to provide children with experiences that will help them develop civic skills and attitudes as well as build their civic identities by helping them find a moral compass that will lead them to civic action. As technology rapidly changes, new tools will be developed and new possibilities for developing civic education programs will emerge. Thus, the question is what will not change even when everything else changes?

People, and our inclination to learn by doing, rather than by being told, won't change. A short answer to this complex question is the need to focus on technologies that allow young people to experiment with "what if" situations, by making, creating, developing, discussing, debating. In the continuum of instructionist to constructionist approaches to civic education programs using technology presented in the earlier typology, I suggest that the focus on constructionist types of experiences should remain. Even when there is a strong push toward knowledge-base approaches that are best suited to test-driven curriculum. The advantage of constructionist and praxis-based models is that they are open-ended. For example, in Zora, teachers can create their own public virtual spaces to directly educate students about civic facts and process. But they can also design an experience in which students will take the lead.

Open-ended technologies allow different kinds of learners to use them in the way it suits them best. For example, some might choose to display content (as the ACT participants did in their virtual exhibits), others to engage in storytelling (as those who used Zora to write stories or values definitions), while others might choose to engage in debates (as those who discussed cases), or to use technology to create or program artifacts as alter egos that represent their point of view through a graphical interactive object (such as the little boy who created the "Everyone's Temple").

Technological tools also need to be open ended to enable different kinds of teachers or after-school coordinators to best integrate them with their own teaching style, curriculum, and state and federal mandates. For example, some teachers might choose to design an experience with unstructured activities, such as the case of the summer camp with young children, while others might like to develop a more structured curriculum, as it was done in ACT. For example, one of the activities was designed to help students evaluate if the 
campus they designed could handle a real-life, controversial community-related issue (e.g., bias incident, cheating). Actual news articles from a college's student newspaper were posted in Zora for students to read and discuss. After discussing the articles, students were asked to present their responses and thoughts somewhere in their virtual campus (e.g., the campus center). In addition, students could go back to their virtual campus and make changes, such as revising or adding services, classes, committees, or resources. Teachers have different styles and curricular needs. Thus the technology needs to be flexible enough to enable all of them to appropriate it.

In sum, the work presented in this chapter shows a concrete example, with a particular kind of technology called Zora, of a praxis-based civic education program with a constructionist use of technology. This work opens up new lines of inquiry to explore questions regarding the impact of on-line civic learning experiences, such as the ones both young children and incoming freshmen had with Zora, on the off-line "real life." For example, is participation in virtual communities affecting youth's civic engagement in face-to-face communities? Are standard on-line technologies (such as e-mail and Internet portals) of value, or do we need specifically designed technologies to promote civic engagement, such as Zora or similar constructionist communities?

If we are going to allocate resources to the development of technology-based civic education programs, we also need to understand the role of adults and mentors. A lot is known about the role of mentors in both on-line communities and face-to-face programs, but what characteristics do mentors need to have to be versatile in both worlds? Do mentors need to be themselves civically engaged to serve the function of role models?

Finally, technological fluency—defined by Seymour Papert as the ability to use and apply technology in a fluent way, effortlessly and smoothly, as one does with language-involves mastering not only technological skills and concepts but also the ability to learn new ways of using computers in a creative and personally meaningful way. During the process of using the technology in a creative way, people are also likely to develop new ways of thinking; therefore the computer's role goes far beyond being an instrumental machine. Thus, we need to understand what level of technological fluency students need to have in order to benefit from technology-based interventions to foster civic engagement?

It is not the goal of this chapter to answer these questions, but simply to pose them. As new research involving new media and civic engagement starts to emerge and the field is establishing itself as an important area in both civic education and educational technologies, the hope is that these questions will illuminate some possible directions for academic research, policy decision making, and practical implementation. While a growing amount of research and educational programs show the benefits of the Internet to gain knowledge about politics and therefore make use of instructionist technologies and knowledge-based approaches, this chapter focuses on how the Internet can provide a safe space to experiment with civic life, by forming on-line communities that extend and augment the possibilities of young people to engage in face-to-face civic conversations, attitudes, and behaviors. This is a less explored terrain that makes use of constructionist technologies and praxis-based models, as presented by Zora.

\section{Notes}

1. Zora is a three-dimensional virtual environment first designed by the author as part of her doctoral work at the MIT Media Lab using the Microsoft Virtual Worlds platform, and later reimplemented and 
extended by Bers and her team at Tufts University using ActiveWorlds. Zora provides tools for youth to build and inhabit their virtual city. Research on Zora can be found in Marina Bers, Identity Construction Environments: Developing Personal and Moral Values Through the Design of a Virtual City, The Journal of the Learning Sciences 10, no. 4 (2001): 365-415; Marina Bers, Joseph Gonzalez-Heydrich, and David Ray DeMaso, Use of a Computer-based Application in a Pediatric Hemodialysis Unit: A Pilot Study, Journal of the American Academy of Child \& Adolescent Psychiatry 42, no. 4 (2003): 493-96; Marina Bers and Clement Chau, Fostering Civic Engagement by Building a Virtual City, Journal of Computer-mediated Communication (2006), http://jcmc.indiana.edu/vol11/issue3/bers.html.

2. Sherry Turkle coined the term social laboratory when analyzing the first experiences of adolescents using the Internet in the early nineties in her book Life on the Screen (Sherry Turkle, Life on the Screen: Identity in the Age of the Internet [New York: Simon \& Schuster, 1995]).

3. The term identity construction environments (ICE) was coined by Bers to refer to technologies and technologically rich psychoeducational programs specifically designed to support positive youth development (Bers, Identity Construction Environments; Marina Bers, The Role of New Technologies to Foster Positive Youth Development, Applied Developmental Science Journal 11, no. 1 [2006]: 200-19).

4. Seymour Papert, pioneer precursor of the use of technologies to promote learning developed the constructionist theory of learning based on his work with Jean Piaget. See Seymour Papert, Mindstorms: Children, Computers and Powerful Ideas (New York: Basic Books, 1980); Seymour Papert, The Children's Machine: Rethinking School in the Age of the Computer (New York: Basic Books, 1993).

5. Research by Molly W. Andolina, Krista Jenkins, Scott Keeter, and Cliff Zukin, Searching for the Meaning of Youth Civic Engagement: Notes From the Field, Applied Developmental Science 6, no. 4 (2002): 189-95; Nakesha Faison and Constance Flanagan, Youth Civic Development: Implications of Research for Social Policy and Programs, vol. XV, Social Policy Report (Ann Arbor, MI: Society for Research in Child Development, 2001); Grantmaker Forum on Community and National Service, The State of Service-related Research: Opportunities to Build a Field (Berkeley, CA: The Grantmaker Forum on Community, 2000); Erik Michelsen, Jonathan Zaff, and Elizabeth C. Hair, Civic Engagement Programs and Youth Development: A Synthesis (Washington, DC: Child Trends, 2002); Robert Kraut, Sarah Kiesler, Bonka Boneva, Jonathan Cummings, Vicki Helgeson, and Anne Crawford, Internet Paradox Revisited, Journal of Social Issues 58, no. 1 (2002): 49-74; Robert Kraut, Michael Patterson, Vicki Lundmark, Sarah Kiesler, Tridas Mukophadhyay, and William Scherlis, Internet Paradox: A Social Technology That Reduces Social Involvement and Psychological Well-being? American Psychologist 53, no. 9 (1998): 1017-31; Norman H. Nie, D. Sunshine Hillygus, and Lutz Erbring, Internet Use, Interpersonal Relations and Sociability: A Time Diary Study, in Internet and the Everyday Life, ed. Barry Wellman and Caroline Haythornwaite (Oxford: Blackwell, 2002), 215-43; and Robert Putnam, Bowling Alone: The Crumbling and Revival of American Community (New York: Simon \& Schuster, 2000) has extensively looked at the decreasing trends in youth civic participation and have, in some cases, blamed technology for this.

6. Interesting work can be found in J. Cassell, "We Have These Rules Inside": The Effects of Exercising Voice in a Children's Online Forum, in Children in the Digital Age: Influences of Electronic Media on Development, ed. Sandra L. Calvert and Amy B. Jordan (Westport, CT: Praeger/Greenwood, 2002), 123-44; Justine Cassell, David Huffaker, Donna Tversky, and Kim Ferriman, The Language of Online Leadership: Gender and Youth Engagement on the Internet, Developmental Psychology 42, no. 3 (2006): 436-39; and Neil Howe and William Strauss, Millennials Rising: The Next Great Generation (New York: Vintage Books, 2000); Jay G. Blumler and Steven Coleman, Realizing Democracy Online: A Civic Commons in Cyberspace, IPPR/Citizen Online Research Publication 2 (2001); Emory H. Woodard IV and Kelly L. Schmitt, Political Socialization in the Digital Age: The "Student Voices" Program, in Children in the Digital Age: Influences of Electronic Media on Development, ed. Sandra L. Calvert, Amy B. Jordan, and Rodney R. Cocking (Westport, CT: Praeger, 2002), 83-99. 
7. See work by Sasha Barab, James G. MaKinster, Julie Moore, David Cunningham, and the ILF Design Team, Designing and Building an Online Community: The Struggle to Support Sociability in the Inquiry Learning Forum, Educational Technology Research and Development 49, no. 4 (2001): 71-96; Jodi Clarke and Chris Dede, Making Learning Meaningful: An Exploratory Study of Using Multi User Virtual Environments (MUVES) in Middle School Science (paper presented at the American Educational Research Association Conference, Montreal, April 2005); Kurt Squire and the Games-to-Teach Research Team, Design Principles of Next-Generation Gaming for Education, Educational Technology 43, no. 5 (2003): 17-23; Constance A. Steinkuehler, Learning in Massively Multiplayer Online Games, in Proceedings of the Sixth International Conference of the Learning Sciences, ed. Yasmin B. Kafai, William A. Sandoval, Noel Enyedy, A. S. Nixon, and Francisco Herrera (Mahwah, NJ: Erlbaum, 2004), 521-28.

8. See Chip Morningstar and Randy Farmer, The Lessons of Lucasfilm's Habitat, in Cyberspace: First Steps, ed. M. Benedikt (Cambridge, MA: MIT Press, 1991), 273-302; S. Jones, Cybersociety 2.0: Revisiting Computer-mediated Communication and Community (Thousand Oaks, CA: Sage, 1998); Marlene Scardamalia and Carl Bereiter, Adaptation and Understanding: A Case for New Cultures of Schooling, in International Perspectives on the Design of Technology-supported Learning Environments, ed. S. Vosniadou and E. De Corte (Hillsdale, NJ: Erlbaum, 1996), 149-63; M. A. Smith and Peter Kollock, eds., Communities in Cyberspace (London: Routledge, 1998).

9. See Marina Bers, A Constructionist Approach to Values Through On-line Narrative Tools, International Conference for the Learning Sciences AACE (1998): 49-55.; Marina Bers, Joseph Gonzalez-Heydrich, and David Ray DeMaso, Use of a Computer-based Application in a Pediatric Hemodialysis Unit; M. Bers, G. Gonzalez-Heydrich, and D. DeMaso, Identity Construction Environments: Supporting a Virtual Therapeutic Community of Pediatric Patients Undergoing Dialysis, in Proceedings of Computer-Human Interaction, ACM (2001), 380-87; Amy Bruckman, Community Support for Constructionist Learning, Computer Supported Cooperative Work 7 (1998): 47-86; Randy D. Pinkett, Bridging the Digital Divide: Sociocultural Constructionism and an Asset-based Approach to Community Technology and Community Building, The 81st Annual Meeting of the American Educational Research Association, New Orleans, LA, 2000; Mitchel Resnick, Amy Bruckman, and Fred Martin, 1996, Pianos Not Stereos: Creating Computational Construction Kits, Interactions 3, no. 6 (1996: 41-50); A. Shaw, Neighborhood Networking and Community Building, in Ties That Bind: Building Community Networks, ed. S. Cisler (Cupertino, CA: Apple Computer Corp, 1994), 134-37.

10. Some of this research can be found in Jeffrey Youniss, James A. McLellan, and Miranda Yates, What We Know About Engendering Civic Identity, American Behavioral Scientist 40, no. 5 (1997): 620-31; Sidney Verba, Kay Lehman Schlozman, and Henry E. Brady, Voice and Equality: Civic Voluntarism in American Politics (Cambridge, MA: Harvard University Press, 1995).

11. This pilot work can be found in the unpublished thesis by Clement Chau (Associations Between Online Civic Engagement and Personal Technological Characteristics Among College Students [unpublished master's thesis, Tufts University, Medford, MA, 2006]).

12. An extended version of this excerpt was first published in Marina Bers, Identity Construction Environments.

13. See work on the just community approach in Donald Reed, Following Kohlberg: Liberalism and the Practice of Democratic Community (Notre Dame, IN: University of Notre Dame Press, 1997) and Lawrence Kohlberg, The Just Community Approach to Moral Education in Theory and in Practice, in Moral Education: Theory and Application, ed. Marvin Berkowitz and Fritz Oser (Hillsdale, NJ: Erlbaum, 1985), 27-89.

14. R. Hart, Children's Participation: From Tokenism to Citizenship (Florence: UNICEF, 1992).

15. For discussion on civic identities see Augusto Blasi, Moral Cognition and Moral Action: A Theoretical Perspective, Developmental Review 3 (1983): 178-210; Augusto Blasi, Moral Identity: Its Role in Moral 
Functioning, in Morality, Moral Behavior and Moral Development, ed. William Kurtines and Jacob Gewirtz (New York: Wiley, 1984).

16. Helen Haste, The New Citizenship of Youth in Rapidly Changing Nations, Human Development 44 (2001): 375-81, has developed this dual model of civic education. See also Judith Torney-Purta, Rainer Lehmann, Hans Oswald, and Wolfram Schulz, Citizenship and Education in Twenty-Eight Countries: Civic Knowledge and Engagement at Age Fourteen (Amsterdam: The International Association for the Evaluation for Educational Achievement, 2001).

17. For an informative discussion of the different paradigms and the history of educational technology, see Timothy D. Koschmann, Paradigm Shifts and Instructional Technology: An Introduction, in CSCL: Theory and Practice of an Emerging Paradigm, ed. Timothy D. Koschmann (Mahwah, NJ: Erlbaum, 1996), $1-24$.

18. Many constructionist environments for learning math have been developed following the Logo tradition.

19. Amy Bruckman and Marina Bers have pioneered the development of constructionist virtual communities.

20. See Jean Lave and Etienne Wenger, 1991, Situated Learning: Legitimate Peripheral Participation (Cambridge, UK: Cambridge University Press, 1991).

21. Elizabeth Montgomery, Barbara Gottlieb-Robles, and Gary Larson, Youth as E-Citizens: Engaging the Digital Generation, Center for Social Media, School of Communication, American University, March 2004.

22. While as an organization Taking ITGlobal could be an example in the constructionist community typology, as it can be learned by reading Raynes-Goldie and Walker's chapter in this volume, the Web site itself does not provide an environment that meets the constructionist standards.

23. For a description of the Positive Youth Development framework and the six C's, see Richard M. Lerner, Jacqueline V. Lerner, Jason Alermigi, Christine Theokas, Erin Phelps, Steinunn Gestsdottir, Sophie Naudeau, Helena Jelicic, Amy E. Alberts, Lang Ma, Lisa M. Smith, Deborah L. Bobek, David RichmanRaphael, Isla Simpson, Elise D. Christiansen, and Alexander von Eye, Positive Youth Development, Participation in Community Youth Development Programs, and Community Contributions of Fifth Grade Adolescents: Findings From the First Wave of the 4-H Study of Positive Youth Development, Journal of Early Adolescence 25, no. 1 (2005): 17-29; and Lonnie Sherrod, Constance Flanagan, and James Youniss, Dimensions of Citizenship and Opportunities for Youth Development: The What, Why, When, Where, and Who of Citizenship Development, Applied Developmental Science 6, no. 4 (2002): 264-72.

24. Erik Erikson, Childhood and Society (New York: Norton, 1950).

25. For a paper about the ACT program see Clement Chau, Ashima Mathur, and Marina Bers, Active Citizenship through Technology: Collaboration, Connection, and Civic Participation, International Conference of the Learning Sciences, Indiana University, Bloomington, IN, 2006.

26. For more information on ACT, please visit http://www.ase.tufts.edu/devtech/vclc/ACTHome.html, accessed July 2007.

27. For a complete description of this experience with younger children, see Marina Bers and Clement Chau, Fostering Civic Engagement by Building a Virtual City. 